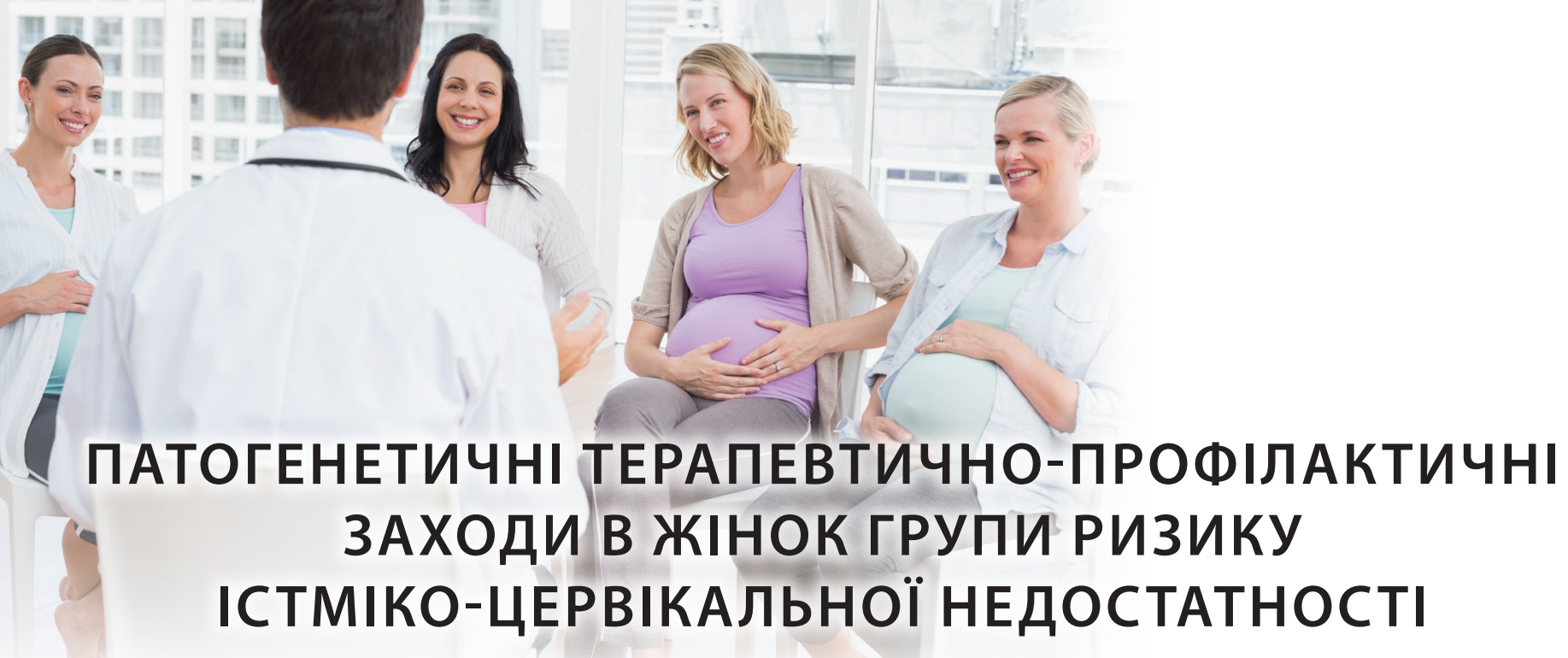

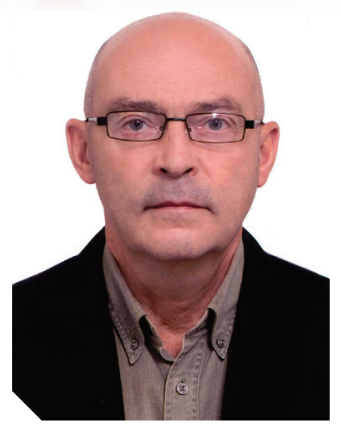

Л.Б. МАРКIH

д. мед. н, професор, членкореспондент НАМН України, завідувач кафедрою акушерства та гінекології Львівського національного медичного університету ім. Данила Галицького ORCID: 0000-0002-7775-4543

\section{Т.Ф. ТАТАРЧУК}

д. мед. н., професор, членкореспондент НАМН України, заступник директора 3 наукової роботи, завідувачка відділенням ендокринної гінекології ДУ «ннститут педіатрії, акушерства та гінекології НАМн України» ORCID: 0000-0002-5498-4143

\section{К.Л. ШАТИЛОВИЧ}

д. мед. н., доцент кафедри акушерства та гінекології Львівського НМу

ім. Данила Галицького

\section{Контакти:}

Шатилович Катерина Леонідівна

Львівський НМУ

ім. Данила Галицького,

кафедра акушерства

та гінекології

79017, Львів, Рапопорта, 8

тел.: +38 (032) 2333211

e-mail: shatik2@ukr.net

\section{ВСТУП}

Частота невиношування вагітності складає $15,5-42,7 \%$ і не має тенденції до зниження. В ґенезі дострокового переривання вагітності одним із провідних чинників $\epsilon$ істміко-цервікальна недостатність (ІЦН). Частота цієї патології в популяції серед вагітних сягає 15\% $[1,2,3]$.

Найбільш розповсюдженим методом терапії ІЦН $\epsilon$ хірургічний цервікальний серкляж. Частота ускладнень при накладанні лікувального шва на шийку матки (ШМ) складає 20-26\%. При цьому основними причинами дострокового переривання вагітності $\epsilon$ розрив плодових оболонок, хоріоамніоніт, прорізування шва на ШМ. Внаслідок розладів фізіологічних реципрокних відношень між тілом і ШМ, обумовлених хірургічною корекцією ІЦН, аномалії пологової діяльності спостерігаються у $14-16 \%$ випадків $[5,13]$.

Наведені дані вказують на актуальність подальшого вдосконалення заходів, спрямованих на профілактику ІЦН.

\section{АНАЛІЗ ЛІТЕРАТУРНИХ ДАНИХ ТА} ПОСТАНОВКА ЗАВДАННЯ ДОСЛІДЖЕННЯ

ІЦН - безсимптомне вкорочення ШМ, розширення внутрішнього вічка, що призводить до розриву плодових оболонок та втрати вагітності. Причини ІЦН численні та різноманітні. Вроджена ІЦН спостерігається при генітальному інфантилізмі, вадах розвитку матки. Органічна ІЦН виникає внаслідок лікувально-діагностичних маніпуляцій, травматичних пологів, що обумовлюють пошкодження ШМ. Функціональна ІЦН супроводжується ендокринними порушеннями (гіперандрогенія, гіпофункція яєчників) [6, 7].

Відомо, що ШМ $\epsilon$ фіброзним органом із високим вмістом колагену. Кількість сполучної тканини (СТ) в ШМ сягає $80 \%$. При розладах синтезу колагену вміст СТ в ШМ знижується до $50-40 \%[8,9]$.
Суттєве значення у формуванні СТ має стан обміну магнію в жіночому організмі. Іони магнію входять до складу основної речовини СТ і беруть участь у регуляціїії метаболізму. В умовах магнієвої недостатності порушується здатність фібробластів продукувати колаген [10].

Відповідно до рішення Міжнародної експертної ради «Дефіцит магнію в акушерстві та гінекології» (Австрія, 2013), нижньою допустимою межею рівня магнію в плазмі крові $\epsilon$ значення в діапазоні 0,80-0,85 ммоль/л. Значення нижче за 0,80 ммоль/л розцінюється як дефіцит магнію (діагноз E61.2 за MKX-10).

Магній - елемент, який не синтезується самостійно в організмі людини і надходить тільки з їжею. В сучасному раціоні дуже мало продуктів з максимальним вмістом магнію нерафінованих злакових, риби, морепродуктів, свіжих фруктів та овочів. При заготовці продуктів для зберігання (сушіння, консервування та ін.) концентрація магнію зменшується незначно, але його біодоступність різко знижується. Ситуацію погіршує поширеність так званого фастфуду (від англ. fast food - швидка їжа), основу якого складає рафінована їжа, 3 надлишком солі та цукру, а також продукти, які виводять магній із організму - наприклад, ортофосфорна кислота в кока-колі та лимонадах, різноманітні консерванти [11].

В умовах магнієвого дефіциту порушується здатність фібробластів продукувати колаген, виникають прояви недиференційованої дисплазії СТ. В результаті спостерігаються розлади пропорційного співвідношення між сполучною та м'язовою тканинами в ШМ, що призводить до раннього її розм'якшення, вкорочення та втрати здатності утримувати плідне яйце до термінових пологів. Частота ІЦН, асоційованої $з$ нутрітивною магнієвою недостатністю, сягає 35\% [12].

В нормі переважна наявність СТ у складі ШМ знижує здатність ультразвукового променя проходити через тканини і підвищує відбивну здатність органа. Ехоструктура ШМ на екрані 
сканера виглядає світлішою за тіло матки. Заслуговує на увагу спосіб діагностики дисплазії СТ у ШМ, який відрізняється тим, що діагностоване при ехографічному дослідженні наближення відбивної здатності ШМ до такої здатності тіла матки за однакових параметрів ультразвукового променя розцінюється як ознака колагенопатії [13].

Як відомо, існує кореляційний зв'язок між параметрами кровоплину в дрібних артеріях ШМ (ДАШМ) і особливостями її морфофункціонального стану [14].

Мета дослідження - дослідити клінічну ефективність застосування препарату Біолектра Магнезіум Фортіссімум у преконцепційній профілактиці ІЦН у жінок із недиференційованою дисплазією СТ на тлі магнієвого дефіциту.

\section{МАТЕРІАЛИ ТА МЕТОДИ ДОСЛІДЖЕННЯ}

Основну групу спостереження склали 50 жінок із підтвердженими лабораторними та інструментальними методами дослідження факторами ризику виникнення ІЦН (гіпомагніємія, зниження індексу резистентності у ДАШМ, УЗ-ознаки дисплазії СТ).

Рівень магнію в плазмі крові жінок визначали колориметричним методом із використанням аналізатора Cobas 600 (с 501 модуль) і тест-системи Roche Diagnostics (Швейцарія). Реєстрували симптоми магнієвого дефіциту (тахікардія, порушення сну, загальна втомлюваність, сонливість, парестезії, судоми м'язів, закрепи).

Із застосуванням діагностичного приладу SA-8000 EX (Medison, Півд. Корея) на відстані 2/3 від внутрішнього вічка і на 1/2 відстані від цервікального каналу до зовнішнього контуру органу за формою судинної кривої, подібної до такої маткової артерії, проводили пошук ДАШМ із подальшим визначенням показника опору кровоплину (IP). IP визначається відношенням різниці між максимальною систолічною і кінцевою діастолічною швидкістю до максимальної систолічної швидкості кровообігу (IP = (А-Д)/A), де A - максимальна систолічна швидкість кровообігу, Д - кінцева діастолічна швидкість кровообігу [15].

Проводили порівняльну оцінку ехоструктури ШМ і тіла матки. При однаковій або майже однаковій інтенсивності М-ехо від ШМ і тіла матки констатували існування сполучнотканинного дефекту [16].

Для корекції магнієвого дефіциту в прегестаційному періоді жінкам основної групи спостереження призначали лікарський засіб Біолектра Магнезіум Фортіссімум (Hermes Arzneimittel GmbH, Німеччина), по 1 шипучій таблетці 1 раз на добу протягом 10 днів з перервою 2 тижні впродовж 3-4 місяців. Одна таблетка препарату містить магнію оксиду легкого 342 мг і магнію карбонату легкого 670 мг, що відповідає іонам магнію 365 мг (=15 ммоль).

Контрольну групу спостереження склали 15 жінок із нормальною концентрацією іонів магнію в крові та неускладненим перебігом гестаційного процесу.

При настанні вагітності у 14-15-тижневому терміні гестації здійснювали комплексну оцінку стану ШМ. Проводили складне сканування в реальному масштабі часу за допомогою трансабдомінального (частота 3,5 МГц) та трансвагінального датчика (частота 7,5 МГц). Вимірювали довжину ШМ і діаметр внутрішнього вічка. У вагітних із відкриттям внутрішнього вічка здійснювали оцінку його форми (Y-, Vабо U-подібна).

Статистичну обробку проводили з використанням програмного забезпечення Statistica 7.0 (Statsoft Inc., США).

\section{РЕЗУЛЬТАТИ ДОСЛІДЖЕННЯ ТА ЇХ ОБГОВОРЕННЯ}

Дослідження вікових показників жінок основної групи спостереження показало, що 58\% з них були у віці від 20 до 29 років, 42\% - у віці від 30 до 40 років. Невисокий соціальний рівень відмічений у $32 \%$ спостережень.

Зловживали тютюнопалінням 16\% вагітних. Професійні шкідливості відзначені у 18\% жінок. Астенічна конституція мала місце у $10 \%$ спостережень. Порушення менструального циклу спостерігалися у 30\% випадків. Анамнез 16\% жінок був обтяжений спонтанними абортами, 8\% - завмерлою вагітністю, 16\% - передчасними пологами, 12\% - народженням дитини з малою масою тіла, 4\% - мертвонародженням, 8\% - неплідністю, 16\% - запальним процесом внутрішніх статевих органів. Гіпоплазію матки встановлено у $4 \%$ жінок, вади розвитку матки - також у 4\%. Операцію на матці та на маткових трубах перенесли по 6\% жінок, на яєчниках - 8\%. У $20 \%$ вагітних діагностовано залізодефіцитну анемію легкого ступеня, у 4\% - вади серця без порушення кровообігу, у $8 \%$ - вегетосудинну дистонію, у 4\% - захворювання нирок, у $6 \%$ - ендокринопатії.

Середнє значення концентрації магнію в плазмі крові пацієнток даної групи складало 0,74 \pm 0,03 ммоль/л. Необхідно зазначити, що зниження концентрації магнію в крові свідчить про наявність вираженого магнієвого дефіциту, оскільки підтримання його нормального вмісту $є$ можливим протягом певного часу за рахунок виходу магнію з депо кісток $[17,18]$.

Клінічна симптоматика магнієвого дефіциту відзначалась у більшості жінок основної групи спостереження. Так, тахікардія мала місце у 28\%, порушення сну - у 24\%, загальна стомлюваність - у 20\%, закрепи - у 18\%, парестезії - у 36\%, судоми м'язів - у $18 \%$ випадків.

Заслуговує на увагу той факт, що в більшості (78\%) спостережень ехографічне дослідження виявило наявність колагенопатії. Спостерігалась однакова або майже однакова відбивна здатність шМ і тіла матки (рис. 1).

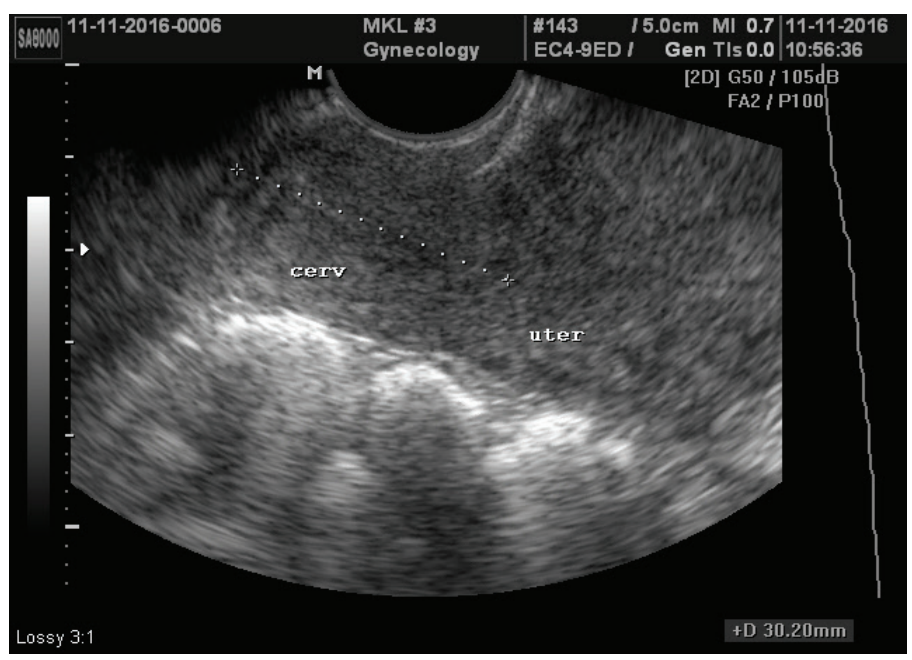

Рисунок 1. Ехограма матки

Ехогенність шийки і тіла матки $є$ однаковими. 
Проведені дослідження також виявили у 86\% жінок достовірне зниження IP $(0,43 \pm 0,03)$ у порівнянні з нормою $(0,65 \pm 0,04, p<0,05)$ в ДАШМ, що свідчило про наявність морфофункціональної недостатності ШМ (рис. 2).

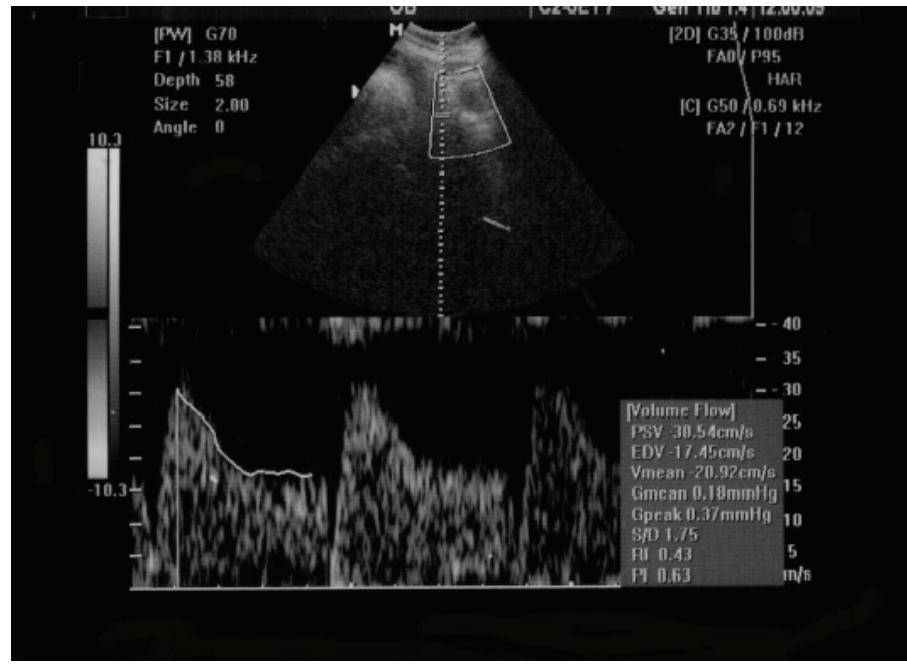

Рисунок 2. Доплерограма ДАШМ

Високий діастолічний компонент. Низький IP.

Застосування Біолектра Магнезіум Фортіссімум при магнієвій недостатності забезпечувало ефективну корекцію гіпомагніємії в жінок основної групи спостереження. Граді$\epsilon н т$ приросту рівня магнію після 3-місячної терапії складав 0,14 \pm 0,03 ммоль/л. Побічні ефекти не спостерігались, пацієнтки відзначали добру переносимість препарату. В більшості випадків відмічена відсутність або зниження частоти й інтенсивності проявів симптомів дефіциту магнію. Так, залишкові явища парестезії мали місце лише у 10\% жінок, судоми м'язів - у $8 \%$.

У 64\% випадків ультразвукове дослідження ШМ виявляло підвищення відбивної здатності органа. Ехоструктура ШМ на екрані сканера виглядала світлішою за тіло матки (рис. 3).

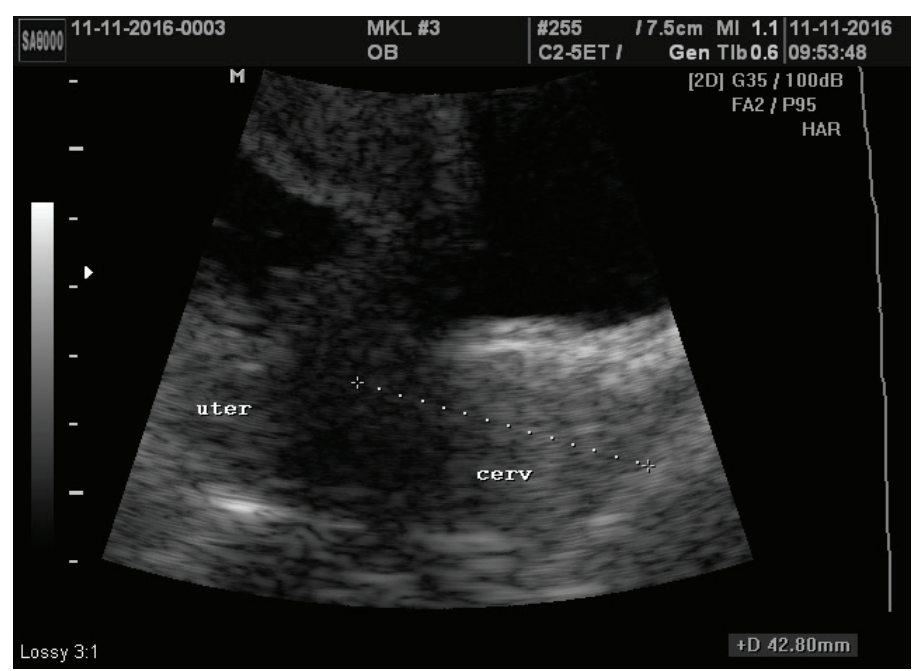

\section{Рисунок 3. Вагітність 14-15 тижнів}

Ехограма шийки матки. Ехогенність шийки вища від ехогенності тіла матки.

Наближення показника опору кровоплину в ДАШМ (IP $0,63 \pm 0,03$ ) відмічено у $60 \%$ жінок (рис. 4).

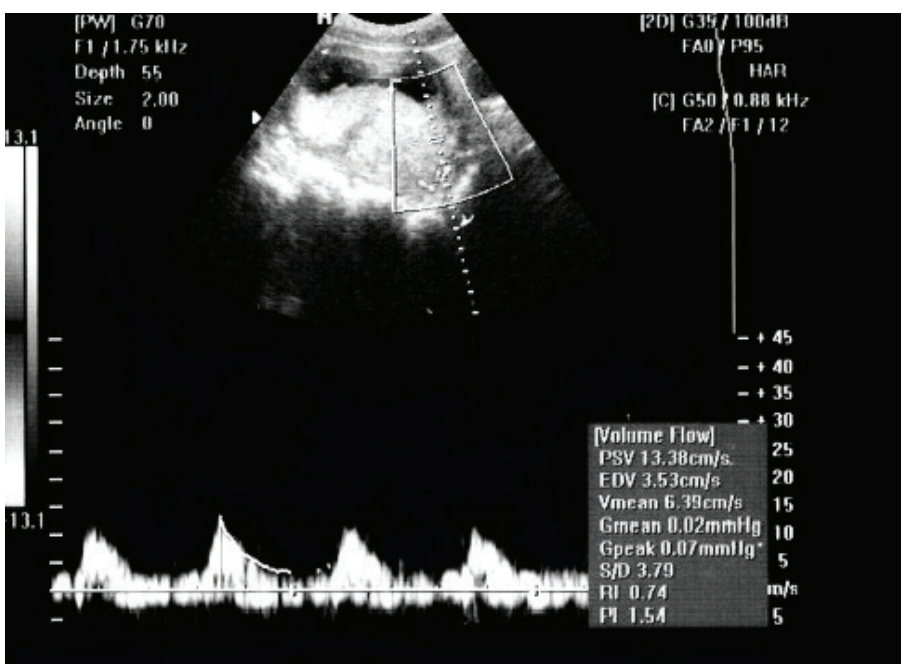

Рисунок 4. Вагітність 14-15 тижнів

Доплерограма ДАШМ. Низький діастолічний компонент. Високий IP.

Усунення магнієвої недостатності сприяло стабілізації колагенових структур, змінам морфофункціонального стану ШМ, нормалізації в органі гемодинамічних процесів.

При прогресуванні вагітності ознаки ІЦН мали місце лише у 20\% жінок. При цьому довжина ШМ дорівнювала 21,3 1 1,2 мм, діаметр внутрішнього вічка - 8,7 \pm 1,3 мм. Форма відкриття внутрішнього вічка у вагітних була переважно V- та $\mathrm{U}$-подібною. В усіх випадках було проведено хірургічне лікування ІЦН.

У більшості (80\%) вагітних основної групи спостереження прояви морфофункціональної неспроможності ШМ були відсутні. Стосовно цих жінок проводився лише моніторинг стану ШМ і перебігу гестаційного процесу.

\section{ВИСНОВОК}

Використання препарату Біолектра Магнезіум Фортіссімум забезпечує ефективну корекцію магнієвого дефіциту в прегестаційному періоді, позитивно впливає на морфофункціональний стан шийки матки і сприяє попередженню ускладнення вагітності істміко-цервікальною недостатністю.

\section{ЛITEPATYPA/REFERENCES}

1. Запорожан, В.М., Цегельський, М.Р., Рожковська, Н.М. Акушерство і гінекологія. Підручник: у 2-х томах. Том 1. - Одеса: Одеський державний медичний університет; 2008. - 472 c.

Zaporozhan, V.M., Tsehelskyi, M.R., Rozhkovska, N.M.

Obstetrics and gynecology. Tutorial: in 2 volumes. Vol. 1. Odesa. Odesa State Medical University (2008): 472 p. 2. Сидорова, И.С., Кулаков, В.И., Макаров, И.0.

Учебник по акушерству. - М.:Медицина, 2006. - С. 331-335.

Sidorova, I.S., Kulakov, V.I., Makarov, I.0.

Tutorial in obstetrics. Moscow. Medicine (2006): P. 331-5.

3. Robboy, $S$.

Pathology of the Female Reproductive Truct. Churchill Livingstone (2002): 929.

4. Дубоссарская, 3.М.

Современный взгяд на этиопатогенез, диагностику и лечение невынашивания

беременности / 3.М. Дубоссарская // Медицинские аспекты здоровья женщины. - 2012. №6 (7). - C. 12-16.

Dubossarska, Z.M.

"Modern view on etiopathogenesis, diagnosis and treatment of miscarriages." Medical aspects of woman's health 6.7 (2012): 12-16.

5. Barth, W.H.

"Cervical incompetence and cerclage: unresolved contraversies." Clyn Obstet Gynecol 34.4 (1994): 831-41. 6. Назаренко, Л.Г.

Прогнозування цервікальної недостатності і втрати вагітності другого триместру / Л.Г. Назаренко, Р.І. Хані // Здобутки клінічної та експериментальної медицини. 2010. - №1. - C. 96-99. 


\section{Nazarenko, L.G., Khani, R.J.}

"Forecasting of cervical insufficiency and loss of pregnancy in the second trimester." Achievements of clinical and experimenta medicine 1 (2010): $96-9$.

7. Голяновський, $0 . B$.

Істміко-цервікальна недостатність: сучасні методи корекції

/ О.В. Голяновський, В.В. Мехедко, І.Д. Галич //

Жіночий лікар. - 2012. - №2. - С. 39-45.

Golianovskyi, 0.V., Mekhedko, V.V., Galich, I.D.

"Isthmicocervical incompetence: modern methods of

correction."Woman's doctor 2 (2012): 39-45.

8. Громова, O.A.

Молекулярные механизмы воздействия магния на дисплазию соединительной ткани / О.А. Громова // Журнал для практикующих врачей. - 2008. - №1. - С. 23-32. Gromova, 0.A.

"Molecular mechanisms of magnesium action on connective tissue dysplasia." Journal for practicing doctors 1 (2008): 23-32. 9. Кадурина, Т.И., Горбунова, В.Н.

Дисплазия соединительной ткани. - СПб: 2009. -701 с.

Kadurina, T.I., Gorbunova, V.N.

Dysplasia of connective tissue. St. Petersburg (2009): 701 p.

10. Кох, Л.И.

Диагностика и результаты лечения истмико-цервикальной недостаточности / Л.И. Кох, И.В. Сатышева // Акушерство и гинекология. - 2011. - №7 (2). - С. 29-32.

Kokh, L.I., Satysheva, I.V.

"Diagnosis and results of treatment of isthmicocervical incompetence." Obstetrics and Gynecology 7.2 (2011): 29-32. 11. Маркін, Л.Б.

Корекція магнієвого дефіциту у вагітних із істмікоцервікальною недостатністю / Л.Б. Маркін, У.Є. Прокіп // Клінічна фармація, фармакотерапія та медична стандартизація. - 2013. - №3-4 (20-21). - С. 78-81.
Markin, L.B., Prokip, U.E.

"Correction of magnesium deficit in pregnant women with isthmicocervical incompetence."Clinical pharmacy, pharmacotherapy and medical standardization 3-4.20-21 (2013): 78-81.

12. Маркін, Л.Б.

Профілактично-терапевтичні заходи при ідіопатичній істміко-цервікальній недостатності/ Л.Б. Маркін,

У.С. Прокіп // Здоровьеженщины. - 2014. - №10 (96). - С. 61-64. Markin, L.B., Prokip, U.E.

"Prophylactic and therapeutic measures for idiopathic isthmicocervical incompetence."Health of a woman 10.96 (2014):61-4.

13. Патент на корисну модель 96950 Україна, МПК (2006.01) A61B 8/08.

Спосіб діагностики дисплазії сполучної тканини у шийці матки // Маркін Л.Б., Прокіп У.Е.; заявник та патентовласник Львівський національний медичний університет ім. Данила Галицького. - № u 2014 10064; заявл. 15.09.2014; опубл. 25.02.2015, Бюл. №4.

Patent for useful model № 96950 Ukraine, IPC (2006.1) A61V $8 / 08$.

Method of diagnosing connective tissue dysplasia in the cervix uteri / Markin, L.B., Prokip, U.E.; applicant and patentee Danylo Halytsky Lviv National Medical University, No. u 2014 10064; appl. 15.09.2014; publ. 25.02.2015, Bull.' Number 8 .

14. Старостина, Т.А.

Диагностическое значение показателей кровотока в маточных артериях и мелких артериях шейки матки при истмико-цервикальной недостаточности /

Т.А. (таростина, А.Д. Липман, А.Ю. Черемных // Акушерство и гинекология. - 1998. - №2. - С. 5-17. Starostina, T.A., Lipman, A.D., Cheremnykh, A.Y.

"Diagnostic value of blood flow parameters in the uterine arteries and small arteries of the cervix uteri in case of isthmicocervical incompetence." Obstetrics and Gynecology 2 (1998): 5-17.
15. Маркін, Л.Б.

Вплив корекції гіпомагніємії на перебіг гестаційного процесу при істміко-цервікальній недостатності / Л.Б. Маркін, У.Є. Прокіп // Международный журнал педиатрии, акушерства и гинекологии - 2015. - №7 (3). - С. 63-64. Markin, L.B., Prokip, U.E.

"Influence of correction of hypomagnesaemia on gestational process during isthmicocervical incompetence." International Journal of Pediatrics, Obstetrics and Gynecology 7.3 (2015): 63-4.

16. Маркін, Л.Б.

Корекція нутрітивної магнієвої недостатності у прегравідарному періоді / Л.Б. Маркін, А.І. Попович,

у.Є. Прокіп // Актуальні питання педіатрії, акушерства та гінекології. - 2015. - № 1. - С. 155-157.

Markin, L.B., Popovych, A.I. Prokip, U.E.

"Correction of native magnesium deficiency in the precognitive period." Actual problems of pediatrics, obstetrics and gynecology 1 (2015): 155-7.

17. Грязнов, Д.А.

Роль дефицита магния в патогенезе метаболического синдрома / Д.А. Грязнов, М.В. Мельник, А.О. Осия // Российский медицинский журнал. - 2008. - №16 (21).

C. 23-28.

Gryaznov, D.A., Melnik, M.V., Osia, A.0.

"The role of magnesium deficiency in the pathogenesis of metabolic syndrome." Russian Medical Journal 16.21 (2008): 23-8.

18. Фофанова, И.

Дефицит магния и его связь с акушерской практикой / и..Ю. Фофанова // Медицинский совет. - 2013. - №5. - С. 31-36. Fofanova, I.Y.

"Magnesium deficiency and its relations with obstetric practice." Medical advice 5 (2013): 31-36. i

\section{ПАТОГЕНЕТИЧНІ ТЕРАПЕВТИЧНО-ПРОФІЛАКТИЧНІ ЗАХОДИ В ЖІНОК ГРУПИ РИЗИКУ ІСТМІКО-ЦЕРВІКАЛЬНОї НЕДОСТАТНОСТІ}

Л.Б. Маркін, д. мед. н, професор, член-кор. НАМН України, зав. кафедрою акушерства та гінекології Львівського НМУ ім. Данила Галицького Т.Ф. Татарчук, д. мед. н., професор, член-кор. НАМН України, заст. директора з наукової роботи, зав. відділенням ендокринної гінекології ДУ «ІПАГ нАМн України» К.Л. Шатилович, д. мед. Н., доцент кафедри акушерства та гінекології Львівського НМУ ім. Данила Галицького

Стаття розглядає проблему істміко-цервікальної недостатності (ІЦН) як одного з провідних чинників в ґенезі дострокового переривання вагітності. Як відзначається, частота цієї патології в популяції серед вагітних сягає 15\%. Представлені результати дослідження, мета якого полягала у дослідженні клінічної ефективності застосування препарату Біолектра Магнезіум Фортіссімум у преконцепційній профілактиці ІцН у жінок із недиференційованою дисплазією сполучної тканини на тлі магнієвого дефіциту.

В дослідженні взяли участь 50 жінок групи ризику ІЦН (гіпомагніємія, зниження індексу резистентності в дрібних артеріях шийки матки (ШМ), Уз-ознаки дисплазії сполучної тканини). Вік жінок коливався від 20 до 40 років. У більшості обстежуваних відзначалась клінічна симптоматика магнієвого дефіциту: тахікардія мала місце у 28\%, порушення сну - у $24 \%$, загальна стомлюваність - у 20\%, закрепи - у $18 \%$, парестезії - у $36 \%$, судоми м'язів - у 18\% випадків. Середнє значення концентрації магнію в плазмі крові пацієнток складало 0,74 $\pm 0,03$ ммоль/л. Проведені дослідження показали достовірне зниження індексу резистентності в дрібних артеріях ШМ у 86\% жінок, що свідчило про наявність морфофункціональної недостатності ШМ. Також у 78\% жінок ехографічне дослідження виявило наявність колагенопатії.

Для корекції магнієвого дефіциту в прегестаційному періоді жінкам призначали лікарський засіб Біолектра Магнезіум Фортіссімум (Hermes Arzneimittel GmbH, Нiмеччина) по 1 шипучій таблетці 1 раз на добу впродовж 10 днів з перервою у 2 тижні протягом 3-4 місяців. Після завершення курсу лікування в більшості випадків відмічена відсутність або зниження частоти й інтенсивності проявів симптомів дефіциту магнію. Градієнт приросту рівня магнію після 3-місячної терапії склав 0,14 00,03 ммоль/л. Залишкові явища парестезії мали місце лише у $10 \%$ жінок, судоми м'язів - у 8\%. У $60 \%$ жінок спостерігалося наближення показника опору кровоплину в дрібних артеріях ШМ (IP 0,63 $\pm 0,03)$ та у 64\% випадків ультразвукове дослідження ШМ виявляло підвищення відбивної здатності органа, що свідчить про стабілізацію колагенових структур, зміну морфофункціонального стану ШМ, нормалізацію в органі гемодинамічних процесів.

Таким чином, використання препарату Біолектра Магнезіум Фортіссімум при магнієвій недостатності забезпечило ефективну корекцію гіпомагніємії, позитивно вплинуло на морфофункціональний стан ШМ, що сприяло попередженню ускладнення вагітності ІцН у $80 \%$ випадків.

Ключові слова: істміко-цервікальна недостатність, магнієвий дефіцит, дисплазія сполучної тканини.

\section{ПАТОГЕНЕТИЧЕСКИЕ ТЕРАПЕВТИЧЕСКИ-ПРОФИЛАКТИЧЕСКИЕ МЕРОПРИЯТИЯ У ЖЕНЩИН ГРУППЫ РИСКА ИСТМИКО-ЦЕРВИКАЛЬНОЙ НЕДОСТАТОЧНОСТИ}

Л.Б. Маркин, д. мед. н, профессор, член-корр. НАМН Украины, зав. кафедрой акушерства и гинекологии Львовского НМУ им. Данила Галицкого

Т.Ф. Татарчук, д. мед. Н., профессор, член-корр. НАМН Украины, зам. директора по научной работе, зав. отделением эндокринной гинекологии ГУ «ИПАГ НАмн Украины»

Е.Л. Шатилович, д. мед. н., доцент кафедры акушерства и гинекологии Львовского НМУ им. Данила Галицкого

Статья рассматривает проблему истмико-цервикальной недостаточности (ИЦН) как одного из ведущих факторов в генезисе досрочного прерывания беременности. Как отмечается, частота этой патологии в популяции среди беременных достигает 15\%. Представлены результаты исследования, цель которого заключалась в исследовании клинической эффективности применения препарата Биолектра Магнезиум Фортиссимум в преконцепционной профилактике ИЦН у женщин с недифференцированной дисплазией соединительной ткани на фоне магниевого дефицита.

В исследовании приняли участие 50 женщин группы риска ИЦН (гипомагниемия, снижение индекса резистентности в мелких артериях шейки матки (ШМ), УЗ-признаки дисплазии соединительной ткани). Возраст женщин колебался от 20 до 40 лет. У большинства обследуемых отмечалась клиническая симптоматика магниевого дефицита: тахикардия имела место у 28\%, нарушения сна - у 24\%, общая утомляемость - у

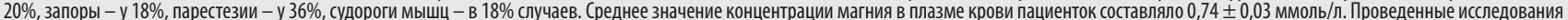
показали достоверное снижение индекса резистентности в мелких артериях ШМ у 86\% женщин, что свидетельствовало о наличии морфофункциональной недостаточности ШМ. Также у $78 \%$ женщин эхографическое исследование выявило наличие коллагенопатии.

Для коррекции магниевого дефицита в прегестационном периоде женщинам назначали препарат Биолектра Магнезиум Фортиссимум (Hermes Arzneimittel GmbH, Германия) по 1 шипучей таблетке 1 раз в сутки в течение 10 дней с перерывом в 2 недели на протяжении 3-4 месяцев. После завершения курса лечения в большинстве случаев отмечено отсутствие или снижение частоты и интенсивности проявлений симптомов дефицита магния. Градиент прироста уровня магния после 3-месячной терапии составил 0,14 $\pm 0,03$ ммоль/л. Остаточные явления парестезии имели место лишь у $10 \%$ женщин, судороги мышц у 8\%. У $60 \%$ женщин наблюдалось приближение показателя сопротивления кровотока в мелких артериях ШМ (ИР $0,63 \pm 0,03)$ и в $64 \%$ случаев ультразвуковое исследование ШМ обнаруживало повышение отражательной способности органа, что свидетельствует о стабилизации коллагеновых структур, изменении морфофункционального состояния ШМ, нормализации в органе гемодинамических процессов. Таким образом, использование препарата Биолектра Магнезиум Фортиссимум при магниевой недостаточности обеспечило эффективную коррекцию гипомагниемии, положительно повлияло на морфофункциональное состояние ШМ, что способствовало предупреждению осложнения беременности ИЦН в 80\% случаев.

Ключевые слова: истмико-цервикальная недостаточность, магниевый дефицит, дисплазия соединительной ткани.

PATHOGENETIC THERAPEUTIC AND PREVENTIVE MEASURES IN WOMEN OF RISK GROUP OF ISTHMICOCERVICAL INCOMPETENCE

L.B. Markin, MD, professor, corresponding member of the NAMS of Ukraine, head of the Obstetrics and Gynecology Department, Danylo Halytsky Lviv National Medical University

T.F. Tatarchuk, MD, professor, corresponding member of the NAMS of Ukraine, deputy director for research work, head of the Endocrine Gynecology Department, SI "Institute of Pediatrics, Obstetrics and Gynecology of the NAMS of Ukraine"

K.L. Shatylovytch, MD, associate professor at the Obstetrics and Gynecology Department, Danylo Halytsky Lviv National Medical University

The article considers the problem of isthmicocervical incompetence (ICI) as one of the leading factors in the genesis of premature termination of pregnancy. As noted, the frequency of this pathology in the population among pregnant women reaches $15 \%$. The results of the study are presented, the purpose of which was to study the clinical effectiveness of the use of the drug Biolectra Magnesium Fortissimum in preconception prevention of ICl in women with undifferentiated connective tissue dysplasia on the background of a magnesium deficiency.

The study involved 50 women at risk of ICI (hypomagnesemia, decrease in the index of resistance in the small arteries of cervix uteri (CU), ultrasound signs of connective tissue dysplasia). The age of women ranged from 20 to 40 years. Most subjects had clinical symptoms of magnesium deficiency: tachycardia occurred in $28 \%$, sleep disorders in $24 \%$, general fatigue in $20 \%$, constipation in $18 \%$, paresthesia in $36 \%$, muscle spasms in $18 \%$ of cases. The mean magnesium concentration in the blood plasma of the patients was $0.74 \pm 0.03 \mathrm{mmol} / \mathrm{l}$. The conducted studies showed a significant decrease in the index of resistance in small arteries of CU in $86 \%$ of women, which indicated the presence of morphofunctional deficiency of CU. Also, in $78 \%$ of women, echographic examination revealed the presence of collagenopathy.

To correct the magnesium deficiency in the pregestation period, women were prescribed the drug Biolectra Magnesium Fortissimum (Hermes Arzneimittel GmbH, Germany) for 1 effervescent tablet once a day for 10 days with a break of 2 weeks for 3-4 months. After completion of the course of treatment, in most cases there was a lack or decrease in the frequency and intensity of symptoms of magnesium deficiency symptoms. The gradient of magnesium level increase after a 3-month therapy was $0.14+0.03 \mathrm{mmol} / \mathrm{l}$. Residual phenomena of paresthesia occurred only in $10 \%$ of women, muscle cramps - in $8 \%$. In $60 \%$ of women, there was an approximation of the blood flow resistance in the small arteries of CU (RI $0.63 \pm 0.03$ ) and in $64 \%$ of cases the ultrasonic examination of CU revealed an increase in the reflectivity of the organ, which indicating stabilization of collagen structures, changes in the morphofunctional state of $\mathrm{CU}$, normalization of hemodynamic processes in the organ.

Thus, the use of drug Biolectra Magnesium Fortissimum in magnesium deficiency provided an effective correction of hypomagnesemia, positively influenced the morphofunctional state of $C U$, which helped prevent the complication of pregnancy in $80 \%$ of cases.

Keywords: isthmicocervical incompetence, magnesium deficiency, connective tissue dysplasia. 